ISSN: 2146-3042

DOI: 10.25095/mufad.607196

\title{
Inflation Targeting and Its Impact on Monetary Policy Post 2008 Crisis: A South African Insight
}

\author{
Emaad MUHANNA** \\ Halah AHMADBEY ${ }^{* * *}$
}

\section{ABSTRACT}

South Africa Inflation Rate declines to 7-Month Low of 4.5\%. The annual inflation rate in South Africa fellto4.5percent in December of 2018, reaching the mid-point of the central bank's target range of 3 percent to 6 percent, from 5.2 percent in the previous month. It is the lowest annual inflation since May as cost of transport slowed sharply. The main task of microeconomic policy is the promotion of sustainable high economic growth, the creation of employment opportunities, the containment of inflation, improvement of the living conditions of all residents of a country, and the elimination of unjustifiable discrepancies in the distribution of income amongst our people. These economic objectives can best be obtained amongst other things in a stable financial environment. Financial instability is a major obstacle in the fulfillment of this task. Stable financial conditions should be maintained throughout the various phases of the business cycle to attain maximum economic development. In addition, inflation could only have an effect on the rate of unemployment if it could somehow affect the real wage in the economy. That is not impossible since the real wage is determined by the marginal productivity of labor in a competitive system.

A number of countries have successfully adapted inflation targeting monetary policy framework in recent years. It is a framework based on hitting an inflation target, and it is considered that the target is going to be missed, then determining whether a change in policy stance is called for. In this paper, we briefly asses the viability of implementing an inflation targeting monetary policy framework in South Africa. The monetary policy in South Africa is conducted by the South African Revenue Bank. Those who have lived in South Africa in the past three decades witnessed dramatic uncontrollable price increase, convincing the Government to take serious measures pertaining to supply and demand of money. The paper furthermore, analyses the impact of inflation targeting on monetary policy in general, with a special focus on South Africa as developing country, highlighting the main strategic approaches implemented as well as the obstacles facing the developing countries and South Africa in particular.

Keywords: Inflation targeting, Finance, Accounting, South Africa, Central Bank

Jel Classification:G01, E52

Makale Gönderim Tarihi: 01.06.2019

Makale Kabul Tarihi: 01.08.2019

Makale Türü: Kuramsal (Teorik) Makale

\footnotetext{
* This paper is presented at the V. International Symposium on Accounting and Finance (ISAF 2019), 1-4 May 2019, Bursa, Turkey.

**Prof. of Political Economy \& Business Administration.Misir University for Science and Technology, Egypt \& Cape Peninsula University of Technology, South Africa. Email: emaad.muhanna@turkgroup.com.tr

***Assistant Professor of Accounting.Former Training Consultant. Egypt Presidential Administration, Egypt. Email:

hala.ahmadbey@gmail.com
} 


\section{INTRODUCTION}

\section{Inflation Targeting: Government Approach}

Since the 1990s, inflation targeting was used more and more in SA, but in an informal and eclectic way. While price stability was pursued, the time period over which this would be achieved was not specified. It was only in the 2000 Budget that formal inflation targeting was introduced. Why the change to a formal framework?

Other than removing uncertainty among the public, formal inflation targeting also improves the coordination between monetary policy and other economic policies followed by government. SA is one of a few countries in the world that stipulated the independence of its central bank in its Constitution. But the Reserve Bank and the Minister of Finance must consult one another regularly and while the Minister of Finance announces the level of the inflation target, a committee consisting of both Reserve Bank and National Treasury members facilitates the process. One of the features of an inflation-targeting framework is the greater degree of transparency it brings to monetary policy. Within a formal framework, targeting a set band, such as our $3 \%$ to $6 \%$ headline CPI, gives credibility to monetary policy and tempers the increases in wages and other operational costs, as well as the price setting by businesses, thereby curbing inflation. The time horizon over which a target is set could also affect its credibility. In SA, one could reasonably expect a change in interest rates to take between 18 and 24 months to fully affect inflation. A multi-year target approach is therefore used in SA.

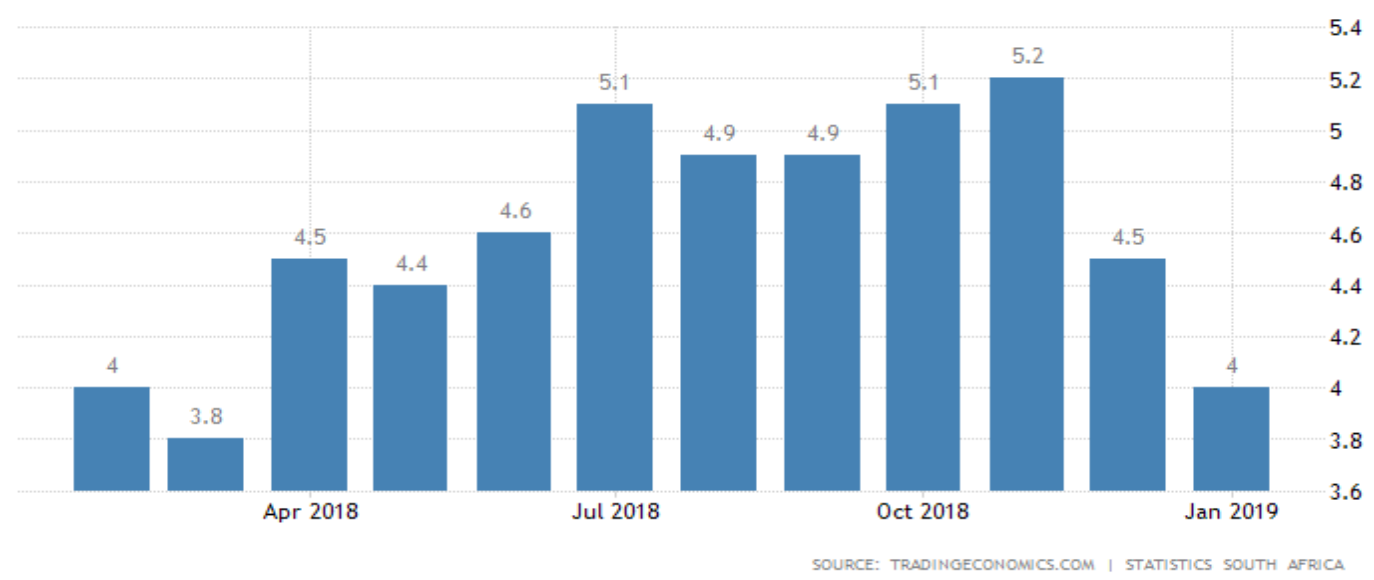

Targeting inflation, a monetary policy strategy which has been successfully used by a number of industrialized countries, has thus become an increasingly attractive alternative that has been adopted by a growing number of emerging market countries, including Chile, Brazil, the Czech Republic, Poland and South Africa.The Reserve Bank of South Africa in 1999, Tito stated that it is advisable to move away from the "eclectic" or informal inflation-targeting monetary policy framework to formal inflation targeting. This change is necessary because the eclectic 
framework has at times created uncertainties about Reserve Bank decisions and actions, which were perceived as being in conflict with the stated guidelines for the growth in money supply and bank credit extension (SA Government Press, 2000).

Looking at some of the comparative data, we see that in the 10 years before inflation targeting was adopted, inflation averaged 9,7 per cent, and this declined to 6,3 per cent in the full inflation targeting period, while average GDP growth improved from 1,6 per cent to 3,3 per cent. The average nominal policy rate declined from 15,5percent to 8,5 per cent, while the average real policy rate declined from 5,7 per cent to 2,2 per cent. If we simply look at the period from 2010, inflation has averaged 5,3 per cent, real GDP growth 2,6 per cent, the repo rate 5,5 per cent and the real repo 0,3 per cent. The volatility of all these variables is also lower in the inflation targeting period. Other positive indicators are the increased contracyclical nature of monetary policy. The SARB's experience during the pre-crisis period, without a focused macro prudential approach, was instructive. During the period 2003-2006, the economy was growing at rates above potential, with an average growth rate of around 5,5 per cent, at atime when the potential growth rate was estimated to have been around 4 per cent. The exchange rate was appreciating, partly in response to the commodity price cycle; annual growth rates in credit extension were around 30 per cent; real household consumption expenditure growth was around 9 per cent; and house price growth was in excess of 30 percent. Since implementing a macro prudential focus, such a combination of settings would have beena cause for concern, and may have elicited a policy response through higher interest rates. However, over that period, inflation was steadily declining and threatening to fall below the lower end of the target range when it reached a low of 3,1 per cent, which could have required a further easing of monetary policy. There was perhaps a shortcoming in terms of recognising this as a broader financial stability risk, and to react either with a tighter monetary policy stance, or with macro prudential tools.

The Reserve Bank of South Africa has adopted a consistent inflation targeting policy, since 2000. On 23 February 2000 the Minister of Finance announced in the Budget Speech that the government had decided to set an inflation target range of 3 to $6 \%$ for the year 2002. The Reserve Bank has therefore formally adopted an inflation-targeting monetary policy framework. This means that the monetary authorities are now targeting the rate of inflation directly instead of following the previously applied "eclectic" monetary policy approach in which intermediate objectives still played a prominent role. In this statement, the new monetary policy framework is explained in more detail. The question may be asked whether the adoption of inflation targeting will lead to a more effective monetary policy (SA Government Press: 2000). As from 25 February 2009 the inflation target is a range of 3 to 6 per cent for the year-on-year increase in the headline CPI (CPI for all urban areas) on a continuous basis. This was announced by the Minister of Finance in his Medium-Term Budget Policy Statement on 21 October 2008. The inflation target is set by government after consultation with the Bank. 


\section{the history of inflation in South Africa}

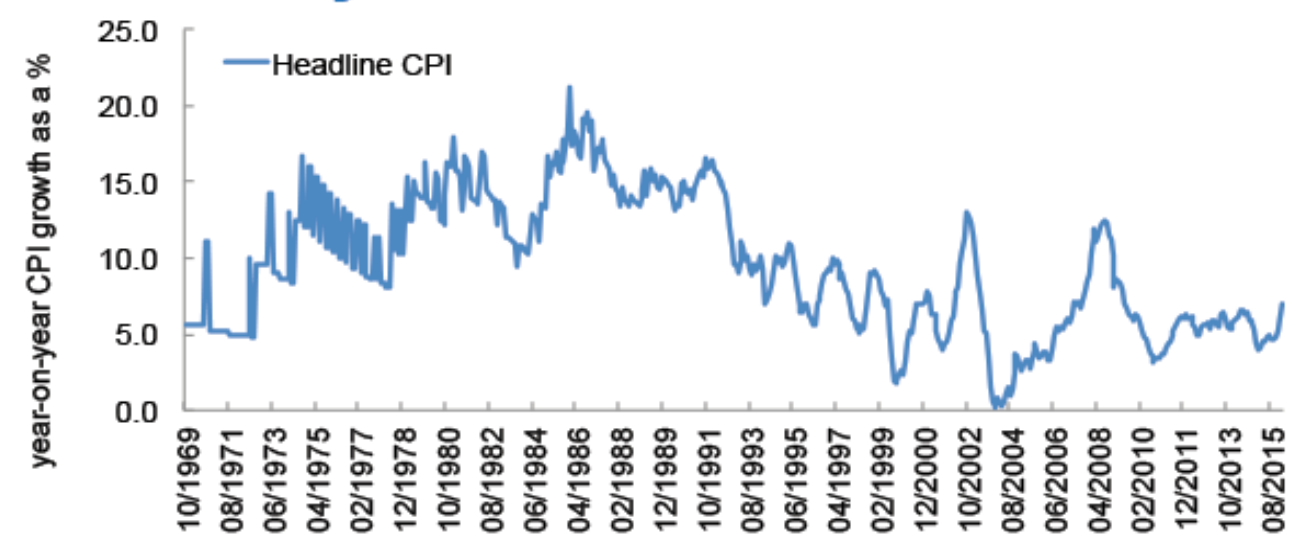

Source: I-Net | March 2016

Since the introduction of the flexible inflation-targeting framework in February 2000, the specification of the target has been reviewed on a number of occasions. The initial target measure was the CPIX, which was defined as the consumer price index for metropolitan and other urban areas, excluding the interest cost on mortgage bonds. This variant of the CPI was chosen because the headline or overall CPI was at that time influenced directly by changes in the Bank's monetary policy. However, following revisions to the methodology employed to compile the CPI, which resulted in, inter alia, a change in the treatment of housing, mortgage interest costs no longer needed to be removed from the CPI when evaluating the effects of monetary policy.

When inflation targeting was introduced, the first target was specified as a calendar year average (for 2002) for CPIX inflation. Subsequent targets were also specified in terms of an average for a particular calendar year. In November 2003 the Minister of Finance announced that the calendar-year averaging would fall away and that the target would apply continuously.

Hitting the ceiling of the South African Reserve Bank (SARB) inflation target range, the CPI comes in at $6 \%$ this month, with a $1,3 \%$ monthly increase. The monthly increase is the largest since June 2008 (1,4\%). The monthly increase has been steadily increasing since a low of $0,1 \%$ in November 2013. Food and non-alcoholic beverages register a 7\% increase, the highest annual rate since August 2013 (7,1\%). Most food groups are showing high inflation, with vegetables having the highest annual rate at $12,8 \%$. Onions and tomatoes both have annual rates over 20\%. March is the month in which excise tax increases are implemented. Alcoholic beverages increased by 2\% between February and March, with a 5,8\% annual increase. In 2014 parents paid on average 8,6\% more for their children's primary school fees and 7,7\% more for secondary school fees than in 2013. The province with the largest change in primary school fees was Northern Cape 10,9\% and Limpopo largest change in secondary school fees of 15,3\%. Continuing with education, the cost of textbooks increased by 13,6\% compared with March 2013. 


\section{INFLATION TARGETING FRAMEWORK}

South Africa formally introduced inflation targeting in February 2000, after announcing the intention to adopt the framework in August 1999. Prior to adopting the inflation-targeting framework, the Bank had adopted a number of frameworks. Between 1960 and 1998, these included exchange-rate targeting, discretionary monetary policy, monetary-aggregate targeting and an eclectic approach.

Inflation targeting is a monetary policy framework in which the central bank announces an explicit inflation target and implements policy to achieve this target directly. One of the features of an inflation-targeting framework is the greater degree of transparency it brings to monetary policy.

Inflation targeting has been adopted in a number of countries. The choice of the target varies across countries. Some countries have opted for target ranges in specifying their inflation targets, while others prefer a point target or a point target combined with a range. The trade-off in this regard is essentially between the simplicity of a point target and the degree of flexibility for absorbing shocks outside the control of the authorities which a target range allows.

It is acknowledged that monetary policy cannot contribute directly to economic growth and employment creation in the long run. However, by creating a stable financial environment, monetary policy fulfils an important precondition for the attainment of economic development.

\subsection{Inflation Targeting: Theoretical Overview}

Inflation targeting is a monetary policy strategy that encompasses five main elements: 1) the public announcement of medium-term numerical targets for inflation; 2) an institutional commitment to price stability as the primary goal of monetary policy, to which other goals are subordinated; 3) an information inclusive strategy in which many variables, and not just monetary aggregates or the exchange rate, are used for deciding the setting of policy instruments; 4) increased transparency of the monetary policy strategy through communication with the public and the markets about the plans, objectives, and decisions of the monetary authorities; and 5) increased accountability of the central bank for attaining its inflation objectives. The list should clarify one crucial point about inflation targeting: it entails much more than a public announcement of numerical targets for inflation for the year ahead. This is important in the context of emerging markets' countries because many of them routinely reported numerical inflation targets or objectives as part of the government's economic plan for the coming year, and yet their monetary policy strategy should not be characterized as inflation targeting, which requires the other four elements for it to be sustainable over the medium term.

One of the primary objectives of monetary policy in any given economy is to protect the value of domestic currency in order to achieve sustainable growth levels. Like fiscal policy, monetary policy is used to control economic and financial stability of an economy. Inflation Targeting is one of the most widely used monetary policy strategies applied to achieve the goal of 
price stability. Proponents of will argue that it is an effective way of ensuring institutional commitment to lower inflation rates, improving communication, transparency and accountability in monetary policy and the central banking system (Mishkin and Posen, 1997; Bernanke, et al, 1999; Fraga, et al, 2003). Critiques however contend that there are better alternatives to this approach and that the gains from inflation targets are dubious (McCallum, 1996; Svensson, 1997). Moreover, the recent global financial crisis has raised further questions about the adequacy of Inflation Targeting.

High Inflation rate is one of the most persistent and exasperating macroeconomic problems facing almost every economy around the world. Monetary authorities across countries are adopting several measures to curb this menace; one of such measures is inflation targeting (IT). Based on the quantity theory of money, inflation is literally viewed as a rise in general price level in an economy. Inflation can lead to price instability, hence causing severe macroeconomic complications- ranging from exchange rate problems to balance of payments deficits and fall in GDP amongst several others. Though not also without faults, it is argued that monetary targeting, exchange rate pegging or nominal GDP targets can be considered as alternatives to IT (McCallum, 1996). These alternatives also contain loopholes which are in fact related to the issue of trade-off between unemployment or output and inflation, time-inconsistency problem, et cetera. (Mishkin and Posen, 1997). Moreover, Mishkin (2000) sites that Latin American and East Asian countries that relied on alternative monetary policy strategies like pegged exchange-rate regimes had found themselves in severe financial crisis in the 1990s.

\section{THE PHILLIPS CURVE}

The idea of a trade-off between inflation and unemployment, or more generally between inflation and growth is one of the most deep-rooted in economics and elsewhere. The general idea is that there is a cost to lowering inflation, in the form of higher unemployment and inversely for a fall in unemployment.

The British economist A.W. Phillips was the first person to investigate this relationship formally, even though he did so purely statistically. The relationship between unemployment and inflation has been known as the Phillip's curve ever since. The subsequent history of the Phillips curve is a woeful tale. First, it provided the opposition for two advances in economic theory:

* The introduction of the expectations as a serious component in monetary policy. modelling.

The introduction of rational expectations as theory-consistent form of expectation-

* The theoretical assault on the Phillips-curve somewhat pre-empted the practical break down of what was a very stable relationship. During the seventies, the inverse relationship between inflation and unemployment turned positive with higher inflation associated with higher unemployment. This disconcerting phenomenon became known as stagflation. 


\subsection{Expectations: The Long Run Philips Curve}

Let us now consider the theoretical underpinning of the long run Phillips curve as it also introduces the importance of expectations in monetary policy. Friedman (1968) and Phelps (1969) were the two architects of what has become known as the vertical Phillips curve and the natural rate of unemployment. Friedman reasoned that in the long run the real forces in the economy (just like for any other real magnitude) determine the rate of unemployment in the economic system. This long run rate of unemployment may not be zero due to factors like frictional unemployment and so on. But this natural rate (where natural refers to the systematic outcome of the system) is independent of the inflation rate.

In the long run the economy is left with a higher rate of inflation and unchanged unemployment. The inflationary expectations have risen in this economy and are factored into the wage negotiations. To lower unemployment again requires not only higher inflation, but accelerating inflation, to keep abreast of the inflationary expectations. This long run Phillips curve is also called the expectations augmented Phillips curve for obvious reasons.

Almost all macroeconomists and central bankers use the idea of a vertical long run Phillips curve. However, there is much disagreement over the short-run trade-off between inflation and unemployment, whereas the new-classical minority argue that the Phillips curve is vertical for all runs.

The argument of the minority is based on the rational expectations hypothesis as modelling strategy in macroeconomic models. I will define rational expectations as model consistent expectations. It follows that rational agents should not be tricked off their supply curves by systematic policy, since this policy is already factored into the optimising decisions of all agents. However, when an unanticipated policy change occurs, then rational agents could be bumped off their supply curves until they have figured out what's going on and returned to their optimum positions.

This is the so-called policy of ineffectiveness position in monetary policy and was one of the most controversial proposals of theoretical macroeconomics during the seventies. The position states that the monetary authorities cannot use systematic policy to affect the real economy. It says nothing about non-systematic policy; however we can make two statements about non-systematic policy:

1. It is not clear how policy could both be non-systematic and based on a scientific analyses of the economy;

2. The idea of the non-systematic policy seems like a non-equitor. Perhaps we should prefer "non-systematic shock".

As an empirical proposition, the PIP-position is probably false. However, we have learnt an important lesson from the subsequent literature, i.e., that there may be an important difference between the effects of anticipated and unanticipated policy. Lately, central banks have gone to 
great lengths to communicate their policies to the public, partly to remove the idea that their actions are arbitrary and mysterious. This transparency is tied closely to the idea of gaining credibility for the monetary policy, which is the next issue we will be examining.

\subsection{What Credibility Is?}

The Kydland and Prescott focus on credibility in the outcome of monetary policy was revolutionary at the time, but it has since captured the centre-ground of both theory and practice in monetary policy. In an interesting survey, Blinder (1999) has found that both academic economists and central bankers emphasized the importance of credibility in monetary policy.

Though everybody seems to agree that credibility is of the greatest importance for central banks, there is much less agreement on what this credibility would mean. Academic economists answer in terms of the incentive effects to prevent the above-mentioned Kydland and Prescott game-theoretic results. Central bankers on the other hand may cite the level of long-term interest rates. Both groups agreed that credibility was very closely associated with the dedication to fight inflation.

Blinder's own definition of credibility is quite useful, i.e.: "a central bank is credible if people believe it will do what it says” (Blinder, 1999: 4) Blinder's survey also revealed why central bankers believed credibility is important:

a. Credibility makes it easier to keep inflation low regardless of whether it lowers the cost of dis-inflation;

b. $\quad$ Credibility makes it less costly to lower inflation.

\subsection{Rules vs Discretion}

Credibility lies at the heart of the rules vs discretion controversy in monetary policy. In practice, it seems that the knock down argument in favour of some form of discretion is that credibility is built not mainly by the technicalities of monetary policy design, but by a consistent record of accomplishment of honesty and fighting inflation.

\subsection{Modern Monetary Policy Regimes}

Modern central banks tend to use one of the four monetary policy regimes. A heart of these regimes is the realisation that the central bank cannot target real quantities in the long-run. The goals of monetary policy are more modest when this is acknowledged:

a. Monetary policy can prevent money from being a source of disturbance in the economy.

b. Monetary policy can contribute to a stable background for economic activity. 
c. But policy can still be used to offset major disturbances. In fact, if central banks are credible the public will find this a credible departure from the standard policy.

\subsection{Money Target}

Friedman was the leader of a vocal group, later called monetarists, who argued for the use of money growth targets as monetary policy regime. In South Africa we have also had money targets at the centre of monetary policy since the eighties even though they have not always been emphasised. Advantages (Mishkin, 1999: 586-587)

1. The target variable (an intermediated target in the goal of containing inflation) is under the control of the central bank as it is narrow definition of money.

2. Allows monetary policy to respond to domestic developments. I allow flexibility to choose a national nominal target, which may differ from those of others.

3. It is rapidly and publicly known whether the central bank is hitting its target.

4. Accountability of the central bank is improved by this public measure of its performance.

5. The rule helps the monetary authorities to communicate their decisions by giving structure and reference to its arguments.

6. The rule helps to reduce inflationary expectations and so help lower actual inflation.

How is money targeting done in practise? (Mishkin, 1999: 588-589)

a. The first step is to define an inflation target and then using the money demand function, calculate the money target consistent with the ultimate goal of monetary policy.

b. The policy is flexible in practice, allowing considerable over and under-shooting.

c. Money targets are used as a framework for explaining decisions by monetary authorities.

d. Mishkin (1999: 588) argues that this communications structure is the main feature of the policy regime.

Lessons from the use of money targets (Mishkin, 1999: 590)

1. Low inflation can be obtained even if the targets are regularly missed.

2. It seems as if the main reason for successful monetary policy in the countries with successful money-targeting regimes is that the objectives of the policy are clearly stated. 


\section{INFLATION TARGETS}

Inflation targeting is the flavour of the month in monetary policy discussion and has been adopted by a growing number of industrialised countries and lately developing countries, too.

According to Mishkin (1999 and 2000) inflation targeting involved the following five steps:

1. Public announcement of the intended target.

2. Institutional commitment to price stability (and especially this target) as primary goal of monetary policy. This is often the problem with developing countries where fiscal reforms consistent with a certain level of inflation have not been implemented. The institutional commitment implies not only changes at the central bank, but also in government, the tax structure and expenditure structure of the government and the banking sector.

3. Use of an information inclusive strategy, with many variables to guide policy, not just single relationship. However, generally, the bank still needs a policy reaction function that relates the variable to the price level. Inflation targeting requires a stable demand for money function, just as money targeting.

4. Transparency must be improved through publications of the Bank and regular communications using the inflation-targeting framework. In this regard, the Boa's inflation report is seen as exemplar. However, this may be propaganda too.

5. Increased accountability at the central bank since their performance can now be measured against the targets. Obviously numerical targets improve accountability. However, there is a difficult question as to when exceptions for breached will be allowed. Further, there are serious questions whether the Bank could possibly hit a point target, and what the purpose of a target is that could not be hit. Further, there is a question whether the improved accountability is at the cost of the independence of the Central Bank.

\subsection{Advantages Of Inflation Pegs}

1. Like money targeting it allows the central bank to pursue domestic objectives too, and to respond to domestic shocks.

2. Mishkin (1999: 591) claims that velocity shocks became irrelevant, in contrast to money targeting. In so far as a velocity shocks is a shock to the demand for money, this is a problematic argument. How will the central bank hit the inflation target without a stable demand for money function?

3. The public can understand the targets easily, making the regime transparent. 
4. Time consistency problems are lessened by the improved accountability of the system.

5. The monetary policy debate could be focused on what monetary policy can hope to achieve, i.e. to stabilise prices.

6. Don’t ignore traditional stabilisation controls - all other features of the business cycle are built into the framework for forecasting inflation.

7. Dangers of deflation can be avoided by using a symmetric response around a point target greater than zero.

8. Flexibility brought by allowing deviations from the target-allowing the Bank to moderate supply shocks.

\section{Inflation Targeting in South Africa}

\section{Characteristics of Inflation Targeting}

A number of industrial countries, such as USA, Canada, the United Kingdom, Sweden, Finland, Australia and Spain, have adopted an inflation-targeting framework during the 1990s. More recently, some of the developing countries have also opted for this monetary policy framework. The Czech Republic has operated a fully-fledged inflation-targeting regime since December 1997. Israel, Chile and Mexico are countries that have one-year inflation targets, while Poland, Hungary and recently Brazil have multi-year inflation targets.

The motives for the adoption of inflation targeting have varied considerably from country to country. In some countries, such as the United Kingdom and Sweden, the collapse of their exchange rates led to inflation targeting in order to assure the public that monetary policy would remain disciplined. Other countries, such as Canada, introduced inflation targeting because of problems experienced with the targeting of monetary aggregates.

Whatever the motives of the countries were, the adoption of an inflation-targeting strategy in all cases reduced the role of formal intermediate targets or guidelines, such as the exchange rate or the growth rate in money supply. Commitment to an intermediate target would be inconsistent with inflation targeting except if it is the only determining factor of inflation. Obviously, this is unlikely. Although growth in money supply is a precondition for a general rise in prices, it is not the only factor that causes inflation.

In an inflation-targeting framework the central bank has to adopt a strategy of determining directly what the likely path of inflation will be. In inflation targeting close attention is typically given to changes in indicators which in the past have affected inflation. This has led to sophisticated models for the prediction of inflation and detailed assessments of factors that could affect it. The prediction of inflation is of the utmost importance in the implementation of 
monetary policy, because changes in policy measures are based on likely future price developments.

The fact that inflation targeting has to rely on forecasting has led to the criticism that this is a weakness of the technique because forecasts are inherently unreliable. Although it is true that an inflation-targeting framework is based on forecasts, it is also true that any other monetary policy framework has to take account of the fact that policy changes will only affect inflation sometime in the future. If the objective of the central bank is the attainment of financial stability, it will always have to take a view on how its current policy stance will effect future price developments, whatever monetary policy framework it decides to pursue. The difference between inflation targeting and other monetary policy frameworks is that inflation targeting makes forecasting explicit and transparent.

The adoption of inflation targeting by a central bank does not mean that the central bank must apply definite rules and is not left with any discretion. Exclusive emphasis on inflation goals over the short-term could lead to a highly unstable real economy in the case of serious supply shocks. If a severe supply shock hits the economy, keeping inflation close to the long-run target could be very costly in terms of lost output. In such cases, some discretion must be applied. Many of the central banks opt for escape clauses in these circumstances. Others have defined the inflation target in such a way that changes in food prices, the price of oil or the effects of value added tax are excluded from the index that they target.

The achievement of the target is, however, also important because it affects the credibility of the central bank. An inflation-targeting framework can only be successful if the public is convinced that the central bank is serious about containing inflation. This means that the government and the central bank cannot simply change to inflation targeting without reference to anyone else. It must ensure that the ordinary people in the street are in favour of price stability. Any misconception that the central bank is not concerned about economic growth and employment creation must be removed. It is important that the public does not get the impression that the central bank is dogmatic about the containment of inflation and does not care about other critical issues of importance to the economy.

It is also important that the public is ensured that there are no hidden agendas, in other words that the objectives stated will be the ones actually pursued. Bill Allen, an official of the Bank of England, in a speech at the Reserve Bank indicated that this was a major issue in the United Kingdom when they adopted inflation targeting in 1992. This was partly due to their mixed historical record at that time in achieving monetary policy objectives and partly because monetary policy had traditionally been conducted in an environment of considerable mystery and secrecy. Fortunately, we have progressed somewhat on both these fronts in South Africa and there should not be any difficulties in switching to inflation targeting. 


\subsection{Advantages Of Inflation Targeting}

What are the advantages of inflation targeting for South Africa?

Firstly, inflation targeting can improve the co-ordination between monetary policy and other macroeconomic policies depending on the way the target is set and whether the target is consistent with other policy objectives. The setting of inflation targets should preferably (but not compulsorily) be a joint effort between the government and the central bank. Inflation targeting will be most effective when economic policies are well co-ordinated. This co-ordination must be clearly spelled out and all stakeholders should be consulted, including business and the trade union movement.

A formalised co-ordinated approach will probably lead to the best results. The Reserve Bank is therefore of the opinion that with the adoption of inflation targets a policy target agreement should be drawn up that would be signed by the Minister of Finance on behalf of Cabinet and the Governor of the Reserve Bank to define precisely the co-ordinated effort needed to contain inflation in pursuit of the broader economic objectives of sustainable high economic growth and employment creation. While this agreement should define the practical implication of the Reserve Bank's goal of price stability, it should also guarantee the instrumental independence of the Reserve Bank.

Secondly, the announcement of inflation targets clarifies the central bank's intentions and reduces uncertainty about the future course of monetary policy. Inflation targets make policy transparent. They make the central bank's intentions explicit in a way that should improve the planning of the private sector.

Thirdly, inflation targeting helps to discipline monetary policy and strengthens the central bank's accountability. If targets are not met, the central bank has to explain what went wrong. This leads to a better understanding on the part of the public on what basis monetary policy decisions were made.

\subsection{Disadvantages of Inflation Targeting}

Although inflation targeting has certain definite advantages when compared with other monetary policy frameworks, it could also have certain disadvantages. One of the limitations of inflation targeting is that it is a complicated approach to implement. Although all monetary policy frameworks should be forward looking, inflation targeting relies heavily on forecasts. Where inaccurate forecasts are made public it can obscure the central bank's objectives and reduce its credibility.

Compared with other monetary policy frameworks there is also the risk that inflation targeting could lead to inefficient output stabilisation. This can occur particularly in the event of significant supply shocks, such as sharp changes in the price of oil. 


\subsection{Preconditions for Inflation Targeting}

In view of these potential disadvantages of inflation targeting, it is important that certain preconditions be met before a decision is taken to implement this framework. In this regard it is important that a central bank is free to pursue financial stability. The inflation target may be jointly set by the government and the central bank. However, once the target has been determined the central bank should be free to use any instrument to achieve the ultimate objective.

In the application of inflation targeting it is further important that there is a commitment by all authorities to the objective of price stability. Preferably, there should be close co-operation between monetary policy and other policies, and in this co-ordinated effort the inflation objective should be an inherent part of overall policy. To implement inflation targeting it is important that well-developed financial markets exist in a country. The policy instruments generally used by monetary authorities require effective money, capital and foreign exchange markets. If financial markets do not react quickly to the instruments applied, it obviously reduces the effectiveness of monetary policy and leads to a delay in influencing inflation.

For the implementation of inflation targeting the central bank must have the necessary resources, i.e. human, technological, etc. Inflation targeting requires sophisticated forecasting models, which need advanced computer hardware and software. In developing economies in particular, this could be an important constraint on the implementation of inflation targeting.

Fortunately, the Reserve Bank's staff should be able to refine and strengthen the Bank's forecasting framework, especially with the help of international experts in this field. The Bank has enough experience in information technology for the implementation of inflation targeting and the other preconditions are generally met in the case of South Africa.

\subsection{The Implementation of Inflation Targeting}

Before inflation targeting is implemented, it is important that:

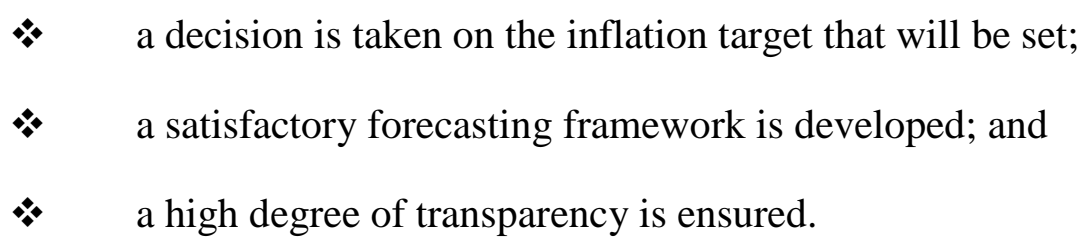

In all inflation targeting countries the practice has been to specify the target in terms of the consumer price index, or some variant thereof. There is, however, no consensus on how inflation should be measured. Preferably, the index should include a range of products whose prices fully describe changes in the cost of living and are generally accepted by the public. Including prices over which policy has no control may lead to misleading signals when these prices move out of line. Policy makers in many instances have accordingly opted for a target that excludes certain measurable components that are unpredictable, volatile or unresponsive to policy. 
In addition, a choice has to be made between setting a single point or a target range. This choice reflects a trade-off - a narrower band may be interpreted as indicating a stronger commitment to the inflation target, but frequent breaches could undermine credibility. A fixedpoint target is much more difficult to hit than a band. A single point provides the best focus for inflation expectations and avoids the disadvantage of a band, which tends to concentrate expectations towards its upper boundary. A band, however, leaves some discretion to the central bank and can provide more flexibility in the case of unforeseen price shocks.

It is also important to decide at what level the target should be set. Preferably it should rather be on the low rather than on the high side. High targets may give the impression that the central bank is not serious about combating inflation. It is accordingly better to lengthen the period over which the target will be reached, than starting at a high level.

The implementation of inflation targeting requires that the authorities must be able to develop a satisfactory forecasting framework. Although South Africa has experienced major structural changes in recent years, it seems that we are in a position to forecast inflation. The Reserve Bank already makes regular inflation forecasts using a large macroeconomic model, which is based on a wide range of financial and economic equations. In the application of inflation targeting it will be prudent to supplement this large model with a number of smaller and single equation models.

Mervyn King, deputy governor of the Bank of England, stated that forecasting, more than any other aspect of economics, brings the discipline into disrepute. Forecasts should not be presented as a single number, but rather as a probability distribution. The Bank of England has accordingly adopted a so-called fan-chart forecasting technique which shows the relatively likelihood of possible inflation outcomes. Careful consideration will have to be given to these techniques of other central banks before inflation targeting was introduced in South Africa.

It is important that the Reserve Bank enhances transparency for the effective operation of an inflation-targeting framework. Transparency introduces predictability, and helps to ensure that expectations are consistent with the objective of price stability, thus lowering the cost of achieving the inflation target. As pointed by prominent economists out many years ago, monetary policy should avoid exacerbating fluctuations of output and employment by introducing unnecessary uncertainty. A transparent monetary policy will mean that changes in short-term interest rates should not surprise the market. Markets should be able to anticipate decisions taken by the Reserve Bank. Transparency should promote the predictability of policy. In this regard Mervyn King has stated that a successful central bank should be boring, it is like a referee whose success is judged by how little his or her decisions intrude into the game. Although the Reserve Bank has progressed considerably in recent years in providing more detailed information to the market and in explaining its policy stance, the Bank has decided that with the introduction of inflation targeting it will improve the transparency of monetary policy further by periodic testimony to Parliament, the regular publication of a monetary policy review report and focused statements after the meetings of the Monetary Policy Committee. In both cases the Bank will 
provide an assessment of how it perceives the underlying economic and financial conditions and explain the monetary policy stance.

\section{A NEW MONITORY POLICY FRAMEWORK}

\subsection{Primary Objective of Monetary Policy}

1.1. The primary objective of monetary policy is to protect the value of the currency in order to obtain balanced and sustainable economic growth in the country. This objective is articulated in both the Constitution of the Republic of South Africa and in the South African Reserve Bank Act of 1996. It requires the achievement of financial stability, i.e. price stability as well as stable conditions in the financial sector as a whole.

1.2 Price stability is achieved when changes in the general price level do not materially affect the economic decision-making processes. Although relative price movements will still have an impact on production, consumption, saving and investment, the rate of inflation or deflation would be so low that it would no longer be an important factor in economic decisionmaking.

1.3 Stable conditions in the financial sector are achieved when there is a high degree of confidence that the financial institutions and financial markets are able to meet contractual obligations without interruption or recourse to outside assistance. Such stable conditions do not preclude the failure of individual financial institutions. A financial institution can fail and be allowed to fail even under stable financial conditions. It is only when the whole, or an important part, of the financial sector is at risk, that the situation can be described as financially unstable.

1.4 The two elements of financial stability, i.e. price stability and the stability of the financial sector, are closely related. Failure to maintain one of these elements provides an uncertain operating environment for the other, with causality running in both directions. For example, high inflation could lead to tighter monetary policy, higher interest rates, an increase in the non-performing loans of banks and a fall in asset and collateral values, which could precipitate bank and other failures in the financial sector. Conversely, disruptions in the financial system will make the transmission of monetary policy less effective and could materially affect changes in the general price level.

1.5 Financial stability is not an end in itself, but is regarded as an important precondition for sustainable high growth and employment creation. By establishing and maintaining financial stability, the monetary authorities make their unique contribution to general economic development in South Africa. If financial institutions and markets are uncertain or unstable it is difficult to produce, consume and invest, and therefore to increase employment. The recent emerging-market financial crisis in 1997 and 1998 has also clearly illustrated that foreign investment can be withdrawn easily and in large amounts from countries that investors perceive as high-risk destinations. Moreover, it is difficult for a country with a high rate of inflation to 
remain competitive in a global environment where more and more countries have already successfully reduced inflation to low levels.

1.6. Inflation has many other disadvantages, such as:

(i) distorting the allocation of resources and often directing the efforts of entrepreneurs and investors into hedging operations instead of productive activity;

(ii) discouraging saving: people spend money now rather than save for investment and future consumption if the expected value is much less;

(iii) discriminating against fixed salaried workers, pensioners and low-income earners who cannot protect themselves against the impact of inflation; and

(iv) usually leading to an even more unequal distribution of income and wealth.

1.7. The new inflation-targeting monetary policy framework is primarily concerned with one element of financial stability, i.e. price stability. For overall financial stability it is important that the Reserve Bank:

(i) ensures the availability of high-quality currency in circulation in various denominations to serve as a reliable means to execute financial transactions in the economy;

(ii) facilitates the development and maintenance of an efficient national payment, clearing and settlement system;

(iii) encourages the development and efficient functioning of the money, capital and foreign exchange markets;

(iv) monitors the financial risks of banks and supports the development of sound and well-managed banking institutions; and

(v) where appropriate acts as lender-of-last-resort assistance providing assistance to solvent banks to safeguard the system from systemic risks arising from temporary liquidity shortages.

\subsection{Inflation Targeting}

2.1. The government decided to set an inflation target as part of a new approach to monetary policy and price stabilisation because of certain advantages that such a framework is expected to have, such as:

(vi) making the objective of monetary policy clear and thereby improving planning in the private and public sectors; 
(vii) forming part of a formalised co-ordinated effort to contain inflation in pursuit of the broader economic objective of sustainable high economic growth and employment creation;

(viii) helping to focus monetary policy and enhancing the accountability of the central bank to the public; and

(ix) providing an anchor for expectations of future inflation which should influence price and wage setting.

2.2 Inflation targeting is a monetary policy framework characterised by an announcement of a numerical target for the inflation rate that is intended to be achieved over a specific time period. In this definition it is important to note that inflation targeting is a framework not a rule, that the numerical rate is made public and that a definite time horizon is specified.

2.3 Although the achievement of the target becomes the overriding objective of monetary policy in an inflation-targeting framework, the adoption of the new framework does not mean that the central bank must apply rigid rules and is left without any discretion. Exclusive emphasis on inflation goals without a careful analysis of economic conditions can lead to serious distortions in the economy which could result in higher inflation over the long term. A rigorously applied rule deprives the central bank of its ability to deal with unusual or unforeseen circumstances.

2.4. In the application of inflation targeting in South Africa allowance will be made for serious supply shocks. Some discretion must be applied in order to avoid costly losses in terms of output and jobs. The Reserve Bank will have to monitor economic developments closely to determine the origin and likely impact of such supply shocks. It is not possible to specify in advance all the economic shocks that could affect monetary policy. Such shocks could include developments affecting the terms of trade of the country or large disruptive international capital flows. They could also arise from natural disasters. If such developments do occur, the public will be duly informed of the likely consequences for attainment of the monetary policy objective.

2.5 It is, however, also important that the inherent discipline of inflation targeting is not foregone by applying discretion. The objective of the exercise is, after all, to achieve the target range. An inflation-targeting monetary policy framework can only be successful if the public is convinced that the central bank is serious about containing inflation. The benefits of inflation targeting depend on whether wage and price setting are responsive to the inflation target of the authorities. Public buy-in is essential to obtain low inflation and its consequent benefits for all. This requires a national effort, anchoring expectations around the inflation range. The challenge that the Reserve Bank faces is to apply this monetary policy framework without becoming too inflexible in its approach.

2.6 The numerical inflation target becomes the ultimate objective of inflation targeting. The immediate focus on intermediate targets such as the growth in money supply and bank credit 
extension falls away because an intermediate target can only be responded to when it is the dominating factor determining inflation within the specified time frame.

2.7 The growth in money supply and bank credit extension will, however, still be monitored closely together with other economic indicators. These include amongst others the level of international interest rates, the shape and position of the yield curve, changes in nominal and real salaries and wages, changes in employment, nominal unit labour costs, the gap between potential and actual national output, general money market conditions, changes in asset prices, the overall balance of payments position, the terms of trade, exchange rate developments and the public sector borrowing requirement.

2.8 The numerical inflation target is announced explicitly to the public to indicate clearly what the Reserve Bank should be held accountable for and to make the application of this framework as transparent as possible. The announcement of the target makes the intentions of monetary policy explicit. If targets are not met, the central bank has to explain what went wrong. Regular reporting on the stance of monetary policy, as is the case internationally, will be made to Parliament.

2.9 The monetary policy stance will also be communicated regularly to the public. This is already done by means of a monetary policy statement after the completion of every meeting of the Monetary Policy Committee. A Monetary Policy Forum has also been established to open an avenue for on-going discussions on monetary policy and general economic developments and to ensure that the views of interested parties are taken into account in the determination of monetary policy. The Monetary Policy Forum will meet twice a year in the major centres of South Africa to allow as many stakeholders as possible to participate in these discussions.

2.10 The Reserve Bank will also publish twice a year a Monetary Policy Review to increase transparency in the application of monetary policy. This Monetary Policy Review will attempt to describe in more detail the decisions taken by the central bank and will analyse developments in South Africa and the rest of the world that could affect inflation.

2.11. These reporting mechanisms should lead to a better understanding on the part of the public of the basis on which monetary policy decisions are made.

2.12 The fact that a definite time horizon is specified in inflation targeting makes it important that the central bank has a reliable forecasting framework. Although South Africa has experienced major structural changes in recent years, inflation still appears to be relatively predictable. The Reserve Bank currently makes regular inflation forecasts using a large, multipurpose, econometric model. However, this model is not suitable for inflation targeting. With the assistance of a number of central banks, the Reserve Bank is in the process of completing the development of a new core model specifically for the forecasting of inflation. In addition to this core model, Philips-curve models, other small-scale macroeconomic models, vector autoregressive models and indicator models are being developed. 


\subsection{Specification of the Inflation Target}

3.1. The inflation target has been specified as achieving an average rate of increase in the overall consumer price index, excluding mortgage interest cost, (the so-called CPIX) of between 3 and $6 \%$ for the year 2002 .

3.2. The authorities opted for a variant of the consumer price index because the headline or overall consumer price index is influenced directly by changes in the Reserve Bank's repo rate through its effect on interest rates. A reduction in the repo rate or a relaxation of monetary policy leads, with a short lag, to a decrease in the consumer price index signalling lower inflation, while an increase in the repo rate or a more stringent monetary policy stance leads, with a short lag as well, to an increase in the consumer price index signalling higher inflation. To overcome this problem, it was decided to exclude mortgage interest cost from the consumer price index for inflation targeting purposes.

3.3. The authorities also decided against using the so-called core inflation rate (i.e. the change in the overall consumer price index excluding the prices of certain food products, interest rates on mortgage bonds, overdrafts and personal loans, value-added tax and property taxes) for inflation targeting purposes, despite certain advantages that the use of this index could have had. The measurement of core inflation has the advantage that it excludes prices directly affected by policy measures as well as some prices over which policy has no direct control and which could lead to misleading signals when these prices are affected by economic shocks. However, it does not exclude the impact of all of these kinds of prices, such as changes in oil prices. The measurement of core inflation has further disadvantages in that it does not comprehensively reflect the cost of living, is difficult for the public to understand and is less credible than headline inflation.

3.4. The Bank in agreement with the Department of Finance therefore opted to target the overall consumer price index excluding mortgage interest cost as measured for metropolitan and other urban areas, CPIX (Mu) 1. Using the consumer price index for only the metropolitan areas would have restricted the measurement of inflation to 14 metropolitan areas. By opting for this more comprehensive measure of inflation, price changes in 53 metropolitan and other urban areas covering approximately, $75 \%$ of all consumption expenditure are taken into consideration in the inflation target. If in due course Statistics South Africa were to broaden the calculations to include the rural areas in measuring the consumer price index, excluding mortgage interest cost, this measure of inflation should be used for inflation targeting purposes.

3.5. The inflation target has been specified as a range or band because it affords the central bank some discretion in taking decisions on the monetary policy stance, and allows for a degree of uncertainty and statistical variability inherent in all economic processes. The range indicates that the Reserve Bank will have been successful in its pursuit of the target if the average annual rate in the stated measure of inflation lies somewhere within 3 to $6 \%$ range in the calendar year 2005. It does not imply that the measured rate must be at the midpoint of this range. If it was 
required that the inflation rate should be at a specific level, a single point target would have been set.

3.6. The time horizon, over which the target must be reached, has been determined as the average rate of increase in the defined index in the year 2005. It will therefore be calculated as the average annual increase in the relevant price index for the year 2002 as a whole. It was decided to use this medium-term target in view of the long lags between monetary policy steps and their impact on inflation. Changes in interest rates in South Africa generally take from 18 to 24 months to have a material influence on the underlying rate of inflation.

\subsection{Monetary Policy Operational Procedures}

4.1. The application of an inflation-targeting monetary policy framework in South Africa will not directly affect the monetary policy operational procedures of the Reserve Bank. As in the past, the Reserve Bank's operations will be aimed at influencing the overall lending policies of banks, and the demand for money and credit in the economy indirectly through changes in bank liquidity and interest rates in the money market.

4.2. The regular repurchase transactions between the Reserve Bank and banks will remain the main apparatus to regulate liquidity in the market. Fine-tuning measures will also be utilised to neutralise temporary fluctuations in bank liquidity and to steer money market interest rates and yields in the desired direction. The instruments that will be used for fine-tuning will consist of additional repurchase or reverse-repurchase transactions, sales or purchases of short-term Treasury bills, Reserve Bank debentures, adjustments in the asset portfolio of the Corporation for Public Deposits, the transferring of government funds between Tax and Loan Accounts at private banks and the Exchequer Account at the Reserve Bank, and foreign currency swaps.

4.3. At times longer-run adjustments may be needed due to structural changes in the liquidity needs of the money market, or because of changes in the monetary policy stance. These adjustments are usually made to increase or decrease the private banks' need for central bank money on a lasting or longer-term basis. In addition to repurchase transactions, outright sales or purchases of domestic securities and variable cash reserve requirements are and will still be applied to adjust the structural liquidity needs of banks.

The inflation targeting, initially adopted by South Africa in 1990, has been the choice of a growing number of central banks in both industrialised and emerging countries. As on November 2000, authors Mishkin and Schmidt-Hebbel had counted 19 inflation-targeting countries. Since then, the numbers have increased. Precisely by how many is debatable and will depend on the precise definition of inflation-targeting countries but I note that the merits of inflation targeting continue to be debated in the US. Inflation targeting in South Africa was formally introduced on 23 February 2000 with the announcement of a 3 to 6\% target for 2002. At that time, CPIX inflation - the rate we target - stood at 7\%. (Just for your information, we define CPIX as the CPI excluding the interest cost of mortgage bonds, for the historical metropolitan and other urban areas). The target range of 3 to $6 \%$ set was an ambitious one. 
Whilst there may be debates today about whether the target range was set at the correct level, it is important to note that for both the credibility of the central bank, as well as the management of expectations in respect of inflation being a problem, the target range had to be set at a level which would properly demonstrate commitment to lowering inflation. In spite of the above-mentioned quite ambitious target, by September 2001, twelve-month CPIX inflation had decelerated to 5,8\% and many analysts thought that the 2002 target would be met fairly easily.

To say the least, circumstances changed! The exchange rate depreciation of some $37 \%$ in 2001 - that is another interesting story! - Mostly in the closing stages of the year, was significantly responsible for pushing up CPIX inflation up to a peak of 11,3\% in November 2002. On 12 September 2002, the Reserve Bank's Monetary Policy Committee had announced the fourth and final 100 basis points increase for the year of the Bank's repurchase rate. As you may well imagine, I was not everyone's most-favourite Governor! Fortunately, inflationary pressures have abated, partly related to the Rand's appreciation since December 2001 and as reflected in the year-on-year change in CPIX falling to 6,6\% in July 2003, and the MPC has seen fit to lower the repo rate. On 14 August 2003, following the most recent meeting of the MPC, the repo rate was further reduced by 100bp to 11\% effective from 15 August 2003. Whilst a Governor is certainly more popular during a declining interest-rate cycle, rest assured there were critics who felt that the Bank had not been bold enough and should have, at least, reduced the repo rate by 150 basis points!

Technically, what the Reserve Bank is doing could more accurately be described as inflation forecast targeting. Given the roughly 12 to 24-month lag between interest-rate changes and their having their full impact felt on inflation, the repurchase rate is set at a level judged to be consistent with bringing inflation to within the target range within an 12- to 24-month time horizon. I am referring to the intricacies of the transmission mechanism, the clear understanding of which represents the single biggest challenge for any inflation-targeting central bank. Inflation targets of 3 to $6 \%$ for 2004 and 2005 have been set by the Government, and guide current policy formulation. Given the lags, current policy changes clearly have virtually no impact on the 2003 inflation outcome; the focus is further ahead.

With the CPIX again approaching the target range, it is relatively easily to somewhat superficially argue the merits of an inflation-targeting regime. Some disadvantages of inflation targeting must, however, be acknowledged. Whilst easily understood in terms of its objective, it is a complicated approach, more demanding and more difficult to implement than a monetary framework based on targeting monetary growth or a more discretionary framework. It implies greater reliance on forward indicators of inflation and a continuous assessment of the relationship between the instruments of monetary policy and the inflation target. Where forecasts turn out to be wrong, even if for completely unforeseeable reasons, the central bank's credibility could be impaired. Of course, the counter-argument being that it simply makes visible the uncertainty that would remain hidden in other monetary-policy frameworks. Inflation targeting, if pursued at any costs, runs the risk of inefficient output stabilisation. Significant supply shocks to the economy such as sharp oil price movements, could require very large monetary-policy adjustments to bring 
inflation back inside the target range within the stated time horizon. For such exceptional events, some discretion and patience in re-achieving the target range should be allowed for.

The advantages of inflation targeting are also worth highlighting. Firstly, transparency the concept is easily understandable, with the ultimate policy objective translated into an explicit target value. Secondly, inflation targeting provides enhanced clarity about the objective of monetary policy, which is conducive to sound planning in both private and public sectors. Thirdly, the framework provides for improved accountability of the Reserve Bank. It eliminates the need to rely on a stable relationship between the money stock and inflation, which has become increasingly difficult to identify; inflation targeting enhances economic policy coordination with government and the central bank both publicly committed to the same inflation target. And lastly inflation targeting provides an anchor for inflation expectations and price and wage setting, thus reducing the friction which arises from widely divergent inflation expectations.

I conclude with the comment that, whilst inflation targeting is certainly no panacea, the Reserve Bank still regards it as the most appropriate framework for achieving relative price stability. I quote from our Annual Economic report 2003, released last week: "Sound and consistent price signals are invaluable in directing resources towards their most efficient uses"; achieving this goal is, we believe, our most important contribution we can make towards optimal economic growth and development.

\subsection{Primary Objective Of Monetary Policy}

The role of the South African Reserve Bank (SARB) in this process is to achieve and maintain price stability and to develop and supervise a healthy banking sector. This objective is spelled out in both the Constitution of South Africa and in the SARB Act. In section 224 of the Constitution and section 3 of the SARB Act it is stated that the primary objective of the Bank is to protect the value of the currency of the Republic in the interest of balanced and sustainable economic growth. This, in our view, means price stability. These laws therefore recognise that only by protecting the currency can balanced and sustainable economic growth be achieved. It is believed in the Bank, and indeed in most other central banks in the rest of the world, that the potential growth rate of an economy and the optimum creation of employment opportunities can only by attained under stable financial conditions. By fulfilling this primary objective, the SARB will be making its contribution to sustainable high economic growth in South Africa.

Section 224(2) of the Constitution determines further that the SARB, in pursuit of its primary objective, must perform its functions independently and without fear, favour or prejudice. Regular consultation must, however, take place between the Minister of Finance and the Governor of the SARB. In addition to this legal requirement, section 10(2) of the SARB Act clearly states that "the rates at which the Bank will discount or rediscount the various classes of bills, promissory notes and other securities shall be determined and announced by the Bank from time to time". This gives the Bank the right to determine the official rate, or as it is now called the repo rate. These laws therefore provide the executive management of the Bank with complete instrumental independence, with the one precondition that regular consultation should take place 
with the Minister of Finance. The Bank can accordingly perform its work in an autonomous manner.

Having established that the task of the Bank is the achievement and maintenance of price stability, what does the term price stability convey? In the economic literature price stability is normally regarded as a situation wherein changes in the general price level do not materially affect the economic decision-making process. Although relative price movements still have an impact on production, consumption and investment, the rate of inflation in such conditions is no longer an important factor in the decisions taken by producers, consumers and investors.

Price stability is heavily dependent on stability in the financial sector. The Bank has accordingly also been tasked to promote the soundness and management of domestic banks through the effective application of international best practise in the regulatory and supervisory area. The objective of banking supervision is to ensure that banks manage their risks in such a way that systemic risk in the banking sector is minimised, thereby ensuring the safety of depositor's money. It is aimed at promoting the financial soundness of banks and the banking system as a whole. In the fulfilment of its mission the Bank performs virtually the full range of functions and duties that are customarily carried out by central banks. The other main functions of the Bank are:

1) the issuing of banknotes and coins;

2) acting as banker to the government;

3) acting as bank to private banks;

4) providing facilities for the clearing and settlement of claims between banks;

5) providing liquidity to banks and acting on a case by case basis as "lender of last resort";

6) engaging in open-market operations; and

7) collecting, processing and interpreting economic statistics and other information.

\subsection{The Importance of Price Stability}

The objective of achieving and maintaining price stability is based on the proposition that inflation is bad for economic growth, employment creation and the distribution of income. Is this indeed the case, or can more growth be attained by allowing an acceleration in inflation?

It is often argued that there is a trade-off between inflation and growth based on the Philips-curve analysis. In this analysis it was argued that at a low level of inflation real economic growth can be stimulated through an expansionary monetary policy even if this policy should lead to higher inflation. There may be some truth in this analysis over the short term, but such a 
policy will not achieve long-term sustainable high economic growth and employment creation. An artificial stimulation of demand inevitably results in higher inflation rather than production over the long term.

If demand is allowed to grow more rapidly than the production capacity of the economy, this leads to inflation. It also results in rising deficits on the current account of the balance of payment. If these deficits are not readily financed by means of financial inflows, the exchange rate of the currency could come under pressure. A depreciating currency can bring further pressures on domestic prices. A little bit of inflation once started can easily gain momentum, which could require very restrictive measures to again attain balance between demand and supply. Substantial swings in interest rates to achieve such a balance make business planning difficult and could lead to lower average economic growth over the long term.

The maintenance of price stability over the long term implies low and more stable interest rates. With low inflation, output increases become more dependent on increases in investment and the quantity and quality of labour, and on the way that these production factors are employed. Economic growth becomes propelled by healthy permanent factors and is not dependent on an artificial stimulation of demand. Low inflation is therefore an important factor for sustainable high growth. In such a stable environment demand and output will grow on a steady and sustainable basis. If price stability is not achieved, the well-known disadvantages of inflation come into play. High inflation distorts the allocation of resources and favours investment in nonproductive hedge assets rather than in capital formation. High inflation discourages saving and leads to more consumption. High inflation erodes the competitiveness of local manufacturers and other producers vis-à-vis foreign producers. High inflation leads to an unfair redistribution of wealth by penalising the poor more than the rich. The general conclusion is accordingly that high inflation in the medium to long term leads to lower growth, fewer jobs, more unemployment and a more unequal distribution of income and wealth.

In analysing these factors, the SARB is acutely aware of the long and variable lags of the effect of interest rate changes on inflation. This is generally believed to be about 18 to 24 months. These lags in monetary policy were an important consideration in the decision to determine directly what the likely path of inflation will be. In adopting an inflation targeting framework the Bank's research has become increasingly focused on the transmission mechanism of monetary policy in South Africa and the development of inflation forecasting models. In co-operation with the staff of other central banks a suite of models was developed, comprising a core model, a small-scale model, vector models, Philips-curve models and indicator models. The prediction of inflation is of the utmost importance in the implementation of monetary policy because changes in policy measures must always be based on likely future price developments. The fact that inflation targeting has to rely on forecasting has led to the criticism that this is a weakness of this framework as forecasts are inherently unreliable. This limitation, however, applies in the case of all other monetary policy frameworks. If the objective of a central bank is the attainment of price stability, it will always have to take a view on how its current policy stance will affect future price developments, whichever monetary policy framework it decides to pursue. The difference 
between inflation targeting and other monetary policy frameworks is that inflation targeting should make forecasting explicit and transparent.

Although the forecasting of inflation is an important tool in deciding on the appropriate monetary policy stance, the SARB still applies discretion in reaching a decision. Every forecast is based on assumptions and no model is perfect. A careful analysis of all economic data and the risks involved is made to ensure that the correct decision is taken. For this reason, the central bank also applies a suite of models to minimise these risks and possible limitations of the individual models.

This analysis of current and possible future developments is important because the achievement of the target is the overriding objective of monetary policy in an inflation targeting monetary policy framework. Such a framework can only be successful if the public is convinced that the central bank is serious about the achievement of the target. Missing the target by a wide margin and consistently will lead to lost prestige and credibility for the central bank. The SARB also realises that exclusive emphasis on inflation goals over the short term could lead to a highly unstable real economy over the longer term. If a severe exogenous shock affects the economy, extreme measures to reach the inflation target could be very costly in terms of lost output and employment. In such cases, some discretion is applied by the Bank. The monetary policy framework at first made allowance for such occurrences by including an escape clause stipulating the circumstances under which the Bank did not need to meet the target. Experience showed that this escape clause created problems in communicating monetary policy decisions. It was accordingly replaced in November 2003 by the introduction of an "explanation clause". In the case of a supply shock the Bank must now fully inform the public of the nature of the shock, the anticipated impact on inflation and the monetary policy response to ensure that inflation returns to the target.

\subsection{Assessment of Inflation Targeting in South Africa}

The inflation target was originally specified as an average annual rate of increase of between 3 and 6\% in the consumer price index for metropolitan and other urban areas excluding mortgage interest costs (the CPIX) for the years 2002 and 2003. In November 2003 it was decided to terminate the annual average specification because it complicates the implementation of the inflation targeting framework and could lead to inconsistencies in monetary policy arising from excessive interest rate volatility and ineffective management of inflation expectations. It was then replaced by a continuous target of 3 to $6 \%$ for the period beyond 2006. In other words, the target is specified as an inflation rate of between 3 and $6 \%$ which must be obtained continuously over a twelve-month period in the coming years.

In 2002 the rate of increase in the CPIX averaged 10\%, or 4 percentage points above the upper limit of the target range. Four exogenous factors were mainly responsible for this inflation outcome. Firstly, the nominal value of the rand on a trade-weighted basis declined by approximately 34\% from the end of June 2001 to the end of that year. Secondly, the prices of food increased by almost 17\% in 2002. Thirdly, the Brent price of oil rose from US\$20 per barrel 
in February 2002 to US\$28 per barrel in December 2002. Fourthly, administered prices increased at very high rates of about $10 \%$ or more in 2002. In view of the effect of these extraordinary events on inflation, the Monetary Policy Committee opted to bring the inflation rate down to target levels in a gradual manner. In January 2002 the first corrective step was taken. At this meeting the Committee increased the repo rate by 100 basis points, followed by a further three increases of 100 basis points at the next three meetings. This brought the repurchase rate to 13,5\% in September 2002, at which level the rate was kept until June 2003. These corrective measures had the desired result. The twelve-month rate of increase in the CPIX slowed down from 11,3\% in November 2002, and moved below the 6\% upper limit of the inflation target range to $5,4 \%$ in September 2003. CPIX inflation then decelerated further to a year-on-year rate of $4,0 \%$ in December 2003, before increasing marginally to 4,2\% in January 2004. For the year 2003 as a whole CPIX inflation averaged 6,8\%.

These developments allowed the SARB to reduce the repo rate by 5,5 percentage points in the second half of 2003. In bringing CPIX inflation down to these lower levels, the restrictive monetary policy stance was assisted by a number of other factors. Particularly important in this regard was the discipline in government finances that helped considerably to reduce inflation expectations. The monetary policy stance was further assisted by a recovery in the exchange rate of the rand from the beginning of 2002 and slower rates of increases in food and energy prices.

It can nevertheless be stated that the consistent application of the inflation targeting monetary policy framework was successful in bringing inflation down to the target range as it is now defined by government. Moreover, the inflation outlook remains favourable. Most analysts and economic commentators, including the SARB, expect CPIX inflation to remain within the inflation target range over the next two years. Inflation is projected to accelerate moderately in the course of 2004 to levels close to the upper limit of the inflation target, followed by somewhat slower rates of increase during 2005. This improved inflation performance should be accompanied by a pick-up in economic growth during 2004 and 2005.

The inflation targeting monetary policy framework not only assisted the Bank in bringing about a better inflation performance, but also strengthened the SARB's mandate to focus on price stability. In previous policy regimes there was no explicit benchmark against which the performance of the Bank could be judged objectively. In the inflation targeting framework, a specific target range is set for a price index to be achieved over a specific time frame, subject to the structural reform of the economy. As already indicated, inflation targeting has also been accompanied by major improvements in the Bank's communication with the public, making monetary policy more transparent. By the specification of a target range, the accountability of monetary policy has been improved. The fact that government decides on the level of the target range has improved the co-ordination between monetary policy and other economic policy measures. To some extent, inflation targeting is already leading to a weakening of the importance of backward-looking inflation in decision-making of business and labour. However, many wage demands are still based on historic inflation figures. It can nevertheless be stated that the introduction of inflation targeting in South Africa has been a big success. 


\subsection{Improvement in International Liquidity Position}

At the end of September 1998, the net open foreign-currency position of the SARB (NOFP) still amounted to US\$23,2 billion, i.e. the difference between an oversold forward book of US\$25,3 billion and net gold and foreign exchange reserves of US\$2,1 billion. At that stage a decision was taken to reduce the NOFP gradually to zero. Underlying circumstances allowed the Bank to reduce this position relatively rapidly to US\$9,5 billion at the end of December 2000. Then a more gradual approach had to be adopted due to the weakness in the external value of the rand. Using only proceeds from privatisation and of funds raised abroad by government, the NOFP was brought down to US\$4,8 billion at the end of 2001. In May 2003 the oversold NOFP was finally converted to an overbought position of US\$0,7 billion.

With the expunction of the oversold NOFP, the SARB shifted its focus to reducing its oversold forward book and to seeking over time to strengthen the official foreign exchange reserve position. The oversold forward book of the Bank amounted to US\$4,7 billion at that time. This oversold forward book was closed out during February 2004. At the end of February 2004, the international liquidity position of the Bank was a positive US\$4,7 billion. Although this is probably still relatively low in relation to some of our significant peers, the achievement of this positive balance has been a major accomplishment. The SARB's focus in the coming years will be to increase this position gradually to higher levels.

\section{CONCLUSION}

In summary, inflation targeting is popular at present. This is consistent with the recognition that low inflation is the primary goal of monetary policy and that anti-inflation policy requires credibility, which is mainly acquired by building a good track record. In short, inflation targeting seems little different from institutionalised pragmatism, which was the fashion a decade ago (Goodheart,1989).

These improvements in the international liquidity position and the lower rate of inflation should provide a platform for the more rapid economic development of South Africa. Stability in interest rates and in the value of the rand is important precondition for the attainment of high economic growth and employment creation. The focus of the SARB will therefore continue to be on the objective of price stability. We can only develop an environment favouring price stability and in this way contribute to the attainment of the other important objectives of economic policy.

Inflation targeting, however, has not been without its domestic critics and political economy challenges. There has been a lot of resistance to the framework from sections of the labour movement in particular, where the idea of a long run trade-off between inflation and employment persists, and, not surprisingly, opposition has tended to intensify during upward phases of the interest rate cycle. This animosity is problematic, as societal buy-in and public support are considered to be important prerequisites for the successful implementation of the framework. 
Although inflation targeting is a difficult monetary policy framework to apply in practice, most of the preconditions for its implementation can be met in South Africa. Inflation targeting should lead to closer economic co-ordination and greater transparency and accountability. It is, however, at the same time important that our house is in order before we implement this framework. In other words we must get our ducks in a row first. The main conclusion is that a fully-fledged inflation-targeting framework would ensure better coordination of monetary and fiscal policy and greater economic policy credibility. There are, however, two important caveats: approval of an explicit inflation targeting framework by government through the Minister of Finance and provision for a lead time of two to three years as part of the implementation strategy.

Finally, the inflation forecast of the SARB has shown a moderate improvement despite the adverse impact of the VAT increase due to be implemented in April. This increase, combined with base effects and other indirect tax increases, implies that the low point of the inflation cycle was reached in the first quarter of 2018, at a forecast average of $4.1 \%$. Headline inflation is expected to average 4.9\% in 2018 (unchanged from the previous forecast), 5.2\% in 2019 (down from 5.4\%), and 5.1\% in 2020. A peak of 5.5\% is expected by the first quarter of 2019 before the VAT increase falls out of the data. The forecast for core inflation is unchanged at $4.6 \%$ for 2018 and is 0.2 percentage points lower, at $4.9 \%$, for 2019 . It is expected to remain unchanged at $4.9 \%$ in 2020.

\section{REFERENCES}

Becker, G., (1992), The Economic Way of looking at Life, Nobel Lecture, (December 9,1992).

Bernanke, B.- T. Laubach, F. Mishkin, - A. Posen (1999), Inflation Targeting: Lessons from the International Experience, Princeton N.J.: Princeton University Press.

Blinder, A.S., (1999), Central Bank Credibility: Why do we care? How do we Build it? NBER Working Paper.

Fischer, S., (1993), “The Role of Macroeconomic Factors in Growth”, Journal of Monetary Economics, vol. 32, no. 3, pp. 485-512.

Fraga, A., I. Goldfajn - A. Minella (2003), “Inflation Targeting in Emerging Market Economies”, NBER Working Paper 10019.

Gibbons, R., (1992). A primer in Game Theory. London: Harvester Wheatsheaf.

Keynes, J.M., (1919), The Economic Consequence of Peace. London: Macmillan and Co. Ltd.

Kydland, F.E., - Prescott, E.C., (1977), "Rules Rather Than Discretion: The Inconsistency of Optimal Plans”, Journal of Political Economy, vol. 85, pp. 473-491.

Abel, A.B., Bernanke, B.S., (1998), Macroeconomics (3rd Edition). New York: Addison Wesley. 
Mankiw, G.N. (1988), "Recent Developments in Macroeconomics: A Very Quick Refresher" Course”, Journal Of Money Credit and Banking, vol. 20, no. 3.

McCallum, B.T. (1996) "Inflation Targeting in Canada, New Zealand, Sweden, the United Kingdom and in General”, NBER, Working Paper 5579.

Mishkin, F. - A. Posen (1997), “Inflation Targeting: Lessons from Four countries”, FR BNY Economic Policy Review, August, pp. 9-110.

Mishkin, F. (2000), “Inflation targeting in Emerging-Market Countries”, The American Economic Review, 90(2), pp. 105-109.

Mishkin, F.S., (2000), Inflation Targeting in emerging Market Countries. NBER working paper 7618.

Mishkin, F. (2004,) “Why the Federal Reserve Should Adopt Inflation Targeting”, International Finance, 7(1), pp. 117-127.

Muhanna, E. (2006), “Inflation Targeting and Its Impact on Monitory Policy: A South African Insight”, Banks and Bank Systems, 1(4), pp. 65-82.

Svensson, L. (1997), "Inflation Forecast Targeting: Implementing and Monitoring Inflation Targets”, European Economic Review 41, pp. 1111-1146.

Zha, T., Identifying Monetary Policy, Federal Reserve Bank of Atlanta Economic Review (second quarter), pp. 26-43 